KS. TOMASZ MOSKAL - LUBLIN

\title{
DUCHOWIEŃSTWO DEKANATU KOPRZYWNICKIEGO W ŚWIETLE WIZYTACJI Z 1782 R.
}

Badania nad duchowieństwem parafialnym Kościoła polskiego w okresie staropolskim mają długą i bogatą tradycję. Przedstawiają one duchowieństwo w aspekcie duchowym (przygotowanie do kapłaństwa, formacja intelektualna i wewnętrzna) jak i materialnym (uposażenie, zarządzanie parafia). Niniejsze opracowanie jest przyczynkiem do poznania tej grupy społecznej w obrębie jednostki administracyjnej kościoła diecezjalnego - dekanatu.

Dekanat koprzywnicki należał w omawianym okresie do archidiakonatu sandomierskiego w diecezji krakowskiej. Jego powstanie datowane jest na przełom XVI i XVII w. ${ }^{2}$ W 1782 r. obejmował on 13 parafii. Były to: Chobrzany, Kleczanów, Koprzywnica, Łoniów, Malice, Niekrasów, Obrazów, Osiek, Samborzec, Sandomierz (kolegiata p.w. Narodzenia NMP, kościół p.w. Nawrócenia św. Pawła Apostoła), Skotniki i Sulisławice. W granicach dekanatu znajdowały się także klasztory męskie: duchaków przy kościele Św. Ducha oraz dominikanów w Sandomierzu: p.w. św. Jakuba oraz św. Marii Magdaleny. Należy wskazać także kolegiatę sandomierską oraz klasztor OO. Reformatów w Sandomierzu, jednakże nie zostały one ujęte $\mathrm{w}$ źródle.

Podstawą prezentowanych badań są akta wizytacji przeprowadzonej w 1782 roku przez ks. Stanisława Ptaszyńskiego, znajdujące się w zasobie Biblioteki Wyższego Seminarium Duchownego w Sandomierzu ${ }^{3}$.

\footnotetext{
${ }^{1}$ M. Aleksandrowicz, Duchowieństwo parafialne archidiakonatu gnieźnieńskiego na poczatku XIII w., RHum 22 (1974), z. 2, s. 38-61; J. Kracik, Potrydencki system rekrutacji duchowieństwa w diecezji krakowskiej XVI - XVIII wieku, AC 10 (1978), 471-493; S. Olczak, Duchowieństwo parafialne diecezji poznańskiej w końcu XVI $i$ w pierwszej połowie XVII w., Lublin 1990; J. Pałyga, Duchowieństwo parafialne dekanatu kazimierskiego w XVII i XVIII wieku, RHum 14 (1966), z. 2, s. 3-40.

${ }^{2}$ J. Rawski, Podziat archidiakonatu sandomierskiego na dekanaty, KDS, 51 (1958), s. 239.

${ }^{3}$ BSDS, sygn. I 1476, Protokót wizyty generalnej 4 dekanatów koprzywnickiego, połanieckiego, zawichojskiego, opatowskiego, odprawiony z rozrzqdzenia Jaśnie Oświeconego Ksiażęcia Imci Poniatowskiego, biskupa Ptockiego, Ksiażęcia Puttuskiego, koadiutora z zupetna jurysdykcja, kra-
} 
$\mathrm{Z}$ tekstu wizytacji wynika, że w dekanacie koprzywnickim pracowało 22 duchownych diecezjalnych oraz 13 zakonnych. Charakteryzując dekanat pod względem zajmowanych funkcji spotykamy: proboszczów (10), przełożonych klasztorów (3), komendarza (1), wikariuszy (17) $)^{4}$, prebendarza (1), kapelana (1), promotora różańcowego (1), brata zakonnego (1).

W niniejszej pracy starałem się przedstawić personalia duchownych oraz ich krótką charakterystykę sporządzoną na podstawie spostrzeżeń wizytatora zapisanych $\mathrm{w}$ tekście wizytacji. Ponadto biogramy zostały uzupełnione informacjami zaczerpniętymi z innych, dostępnych źródeł.

Baberzyński Jędrzej CSSp; ur. w 1717 r.; profesję zakonną przyjął w 1724 roku; święcenia kapłańskie przyjął w 1746 r. z rąk sufragana i oficjała poznańskiego Józefa Pawłowskiego 5 . Pracował przy kościele Ducha Świętego w Sandomierzu od 1 lipca $1774 \mathrm{r}^{6}$.

Borucki Feliks OP; ur. w 1725 r.; wstapił do zakonu w 1742 r.; święcenia kapłańskie przyjął w 1749 r. Podprzeor klasztoru przy kościele p.w. św. Jakuba w Sandomierzu od $1782 \mathrm{r}^{7}$.

Bożański Sebastian; ur. 17 stycznia 1730 r.; święcenia kapłańskie przyjął 27 maja 1759 r. z rąk biskupa Kajetana Sołtyka ${ }^{8}$. Instytuowany na kapelanię w Koprzywnicy (kościół p.w. Ducha Świętego) 23 czerwca 1766 r. w Kielcach. Rekolekcje odprawił w marcu 1782 r. Prawo do słuchania spowiedzi otrzymał 24 lipca na jeden rok $^{9}$.

Był to kapłan pobożny, dobry rządca parafii. $Z$ własnych dochodów remontował kościół, budynki plebańskie oraz szpital. Swoją działalnością zyskał sobie szacunek i uznanie parafian. Szczególną troska, jak wskazał wizytator, powinien otaczać szpital w którym miała być odpowiednia liczba ubogich, którzy swoim złym zachowaniem (pijaństwem czy kłótniami) nie powinni siać zgorszenia. Groziło im za to pozbawienie jałmużny lub wydalenie ze szpitala ${ }^{10}$.

\footnotetext{
kowskiego ksiażęcia Siewierskiego, orderów Orła Białego i S. Stanisława kawaler, roku 1782. Przez W. J. X. Stanisława Ptaszyńskiego, kanonika katedralnego Inflanckiego, proboszcza Nowomieyskiego [dalej: Protokót wizyty], s. 118 - 249.

${ }^{4}$ Do wikariuszy zaliczyłem zakonników pełniących różne funkcje w klasztorze.

${ }^{5}$ Józef Pawłowski (1698-1759), sufragan poznański, por. P. Nitecki, Biskupi Kościoła w Polsce 965-1999, Warszawa 2000 [dalej: P. Nitecki, Biskupi], kol. 338.

${ }^{6}$ Protokót wizyty, s. 215.

${ }^{7}$ Tamże, s. 227.

${ }^{8}$ Kajetan Sołtyk (1715-1788), koadiutor i biskup kijowski, biskup krakowski, por. P. Nitecki, Biskupi, kol. 410-411).

${ }^{9}$ Protokót wizyty, s. 136.

${ }^{10}$ Tamże, s. 136.
} 
Ciżlewicz Marcin; ur. 13 listopada 1744 r.; święcenia kapłańskie przyjął 3 maja 1772 r. z rąk sufragana lubelskiego Kantego Lenczowskiego ${ }^{11}$. Prowizję na wikariat w Chobrzanach otrzymał 23 marca 1772 r. Odprawił rekolekcje 21 sierpnia $1772 \mathrm{r}^{12}$. Swoją pracą duszpasterską zasłużył na uznanie w oczach wizytatora ${ }^{13}$.

Danecki Józef CSSp; święcenia kapłańskie przyjął 19 września 1778 r. Pracował przy kościele Ducha Świętego w Sandomierzu od 14 kwietnia 1782 r. ${ }^{14}$

Dąbrowski Augustyn (imię zakonne, na chrzcie Gabriel) CSSp; ur. 16 sierpnia 1723 r.; wstapił do zakonu 2 marca 1754 r.; święcenia kapłańskie przyjął 27 września 1758 r. Pracował przy kościele Ducha Świętego w Sandomierzu od 29 listopada 1778 r. Otrzymał aprobatę do słuchania spowiedzi 14 lipca 1781 r. po odprawionych rekolekcjach ${ }^{15}$.

Domański Franciszek; w 1782 r. proboszcz w Osieku. Zaczął budować folwark plebański w 1809 r. ${ }^{16}$

Był to kapłan pobożny, jednający swoją postawą wspólnotę parafialną. Ze szczególnym pietyzmem opiekował się wyposażeniem liturgicznym kościoła. Wizytator doceniał jego troską o świątynię. Wskazał jednak, że należy jeszcze dokonać niezbędnych remontów kościoła, zabudowań gospodarczych oraz szkoły, zbudować nową dzwonnicę lub naprawić stara, odnowić ogrodzenie cmentarza, spłacić pozostałe długi. W trosce o zapewnienie wystarczającej liczby kapłanów do posługi duszpasterskiej, proboszcz miał zatrudnić dwóch księży do pomocy, a na większe święta sprowadzać jaszcze kilku. Uwadze wizytatora nie uszła także szkoła parafialna, którą należało na nowo zorganizować. Wskazał również, że Bractwo Różańcowe winno być otaczane większą uwagą ${ }^{17}$.

Dudziński Jan; ur. 3 stycznia 1753 r.; święcenia kapłańskie przyjął 1 maja 1777 r. z rąk sufragana krakowskiego Franciszka Potkańskiego ${ }^{18}$. Aplikate na wikariat w Obrazowie otrzymał 28 maja 1777 r. w Krakowie. Aprobata do słuchania spowiedzi została wystawiona 12 marca 1782 r. po odprawionych rekolek$\operatorname{cjach}^{19}$.

Fitowski Stefan Franciszek; ur. 31 grudnia 1744 r.; święcenia kapłańskie przyjął 21 grudnia 1777 r. z rąk sufragana chełmskiego Jana Aleksandrowicza ${ }^{20}$.

\footnotetext{
${ }^{11}$ Jan Leńczowski (+1807), sufragan krakowski, biskup lubelski, por. P. Nitecki, Biskupi, kol. 243.

${ }^{12}$ Protokót wizyty, s. 172.

${ }^{13}$ Tamże, s. 172.

${ }^{14}$ Protokól wizyty, s. 215.

${ }^{15}$ Tamże, s. 215.

${ }^{16}$ Protokół wizyty, s. 152; J. Wiśniewski, Dekanat sandomierski, Radom 1915, s. 125.

${ }^{17}$ Tamże, s. 153-154.

${ }^{18}$ Potkański Franciszek (1710-1789), sufragan krakowski, por. P. Nitecki, Biskupi, kol. 357-358.

${ }^{19}$ Protokót wizyty, s. 248.

${ }^{20}$ Jan Aleksandrowicz (1728-1781), biskup chełmski, por. P. Nitecki, Biskupi, kol. 5.
} 
Instytuowany na prebendę różańcową w Koprzywnicy (parafia p.w. Wszystkich Świętych) 14 listopada 1776 r.; wprowadzony 1 stycznia 1777 r. Rekolekcje odprawił 17 marca 1782 r. Aprobatę do słuchania spowiedzi otrzymał 25 lipca $1782 \mathrm{r}^{21}$.

Janicki Lukasz; ur. 25 października 1723 r.; święcenia kapłańskie przyjął 28 marca 1750 r. z rąk biskupa krakowskiego Andrzeja Stanisława Załuskiego ${ }^{22}$. Aplikatę na wikariat w Sandomierzu (parafia p.w. Nawrócenia Świętego Pawła) otrzymał w grudniu $1779 \mathrm{r}$. Aprobata do słuchania spowiedzi została wystawiona 1 czerwca 1782 r. przez oficjała sandomierskiego ${ }^{23}$.

Był to kapłan, któremu wizytator nie zarzucał jakiejkolwiek niedbałości. Ze względu na wiek i chorobę oczu miał być przeniesiony do Domu Księży Emerytów ${ }^{24}$.

Janowski Jakub (imię zakonne, na chrzcie Kanty) CSSp; ur. 24 lutego 1739 r.; profesje zakonną przyjął 24 lipca 1760 r.; wyświęcony na kapłana 21 kwietnia 1764 r. przez sufragana krakowskiego Franciszka Potkańskiego ${ }^{25}$. Instytuowany na proboszcza w Sandomierzu (kościół Ducha Świętego) 27 czerwca 1774 r. Aprobatę do słuchania spowiedzi otrzymał 10 czerwca 1782 r. po rekolekcjach odbytych 2 maja $1782 \mathrm{r}^{26}$.

Była bardzo dobrym zarządcą kościoła i klasztoru. Przyczynił się do powiększenia budynków klasztornych, wybudował przybudówkę, w której umieszczone zostały kuchnia oraz refektarz. $Z$ równie wielka troską zajmował się przebywającymi w szpitalu ubogimi. W zaleceniach na przyszłość znalazły się m.in. postawienie krzyża na sygnaturce, otynkowanie cel zakonników, odnowienie dachu na kościele i klasztorze, remont zabudowań gospodarczych.

Jasiński Mateusz; ur. 5 września 1725 r.; zm. 16 czerwca 1791 r.; święcenia kapłańskie przyjął 6 lipca 1749 r.; kanonik honorowy sandomierski od 1766 r.; penitencjarz od 1770 r.; kanonik prebendy Piekary od 1774 r.; proboszczem w Sandomierzu (parafia p.w. Nawrócenia Świętego Pawła) został 10 kwietnia 1774 r.; dziekan koprzywnicki od 21 grudnia 1766 r.; Aprobatę do słuchania spowiedzi otrzymał 8 lutego 1782 r. Jako sekretarz Jana Kantego Ligęzy wraz z nim odbył wizytacje archidiakonatu sandomierskiego w 1765 r. ${ }^{27}$

W czasie wizytacji otrzymał zalecenie, by zatrudnił w parafii nowego wikarego, gdyż dotychczasowy, ks. Łukasz Janicki, z racji wieku przygotowywał się do przejścia do Domu Emerytów. Wizytator zalecił ponadto dokładniejsze prowa-

${ }^{21}$ Protokót wizyty, s. 130.

${ }^{22}$ Andrzej Stanisław Załuski (1695-1758), biskup krakowski, por. P. Nitecki, Biskupi, kol. 506.

${ }^{23}$ Protokót wizyty, s. 197.

${ }^{24}$ Tamże, s. 198-199.

${ }^{25}$ Potkański Franciszek (1710-1789), sufragan krakowski, por. P. Nitecki, Biskupi, kol. 357-358.

${ }^{26}$ Protokót wizyty, s. 215.

${ }^{27}$ Protokół wizyty, s. 197; J. Wiśniewski, Katalog prałatów i kanoników sandomierskich od 1186 do 1929 r. tudzież sesje kapituly sandomierskiej od 1581 do 1866 r., Radom 1928 [dalej: J. Wiśniewski, Katalog], s. 93; J. Wiśniewski, Dekanat, s. 97. 
dzenie metryk parafialnych oraz utrzymywanie większej ilości chorych w szpitalu, jak również wskazał na potrzebę remontów dachu na kościele, plebani i wikariacie $^{28}$.

Jastrzębiowski Marcin; ur. w 1751 r.; święcenia kapłańskie przyjął 2 lipca 1780 r. Prowizję na wikariat w Sulisławicach otrzymał w 1780 r. Aprobata do słuchania spowiedzi została mu udzielona na jeden rok od 23 lipca $1781 \mathrm{r}^{29}$.

Kochański Tomasz OP; ur. 14 kwietnia 1738 r.; profesję zakonną przyjął 18 sierpnia 1761 r.; wyświęcony na kapłana 18 grudnia 1762 r. Pracował przy kościele p.w. św. Marii Magdaleny w Sandomierzu jako kaznodzieja od 12 grudnia $1782 \mathrm{r}^{30}$.

Krokowski Kazimierz Walenty SJ; ur. 17 lutego 1732 r.; syn Jana i Franciszki z domu Spendowskiej; święcenia kapłańskie przyjął w 1762 r. we Lwowie z rąk arcybiskupa lwowskiego Hieronima Sierakowskiego ${ }^{31}$. Był profesorem retoryki we Włodzimierzu 1763-1764, teologii moralnej w Seminarium we Włodzimierzu 1765-1766, misjonarzem w województwie sandomierskim 1766-1770 Instytuowany na probostwo w Skotnikach 10 maja 1782 r. w Kielcach; wprowadzony 26 maja 1782 r. Aprobatę do słuchania spowiedzi otrzymał 16 października 1781 r. Rekolekcje odprawił w Sandomierzu 10 grudnia 1781 r. ${ }^{32}$

Był to kapłan o wielkiej wiedzy, głoszący nauki rekolekcyjne w diecezji krakowskiej. Z własnych dochodów pokrył wiele wydatków kościoła i parafii. W świetle zachowanej relacji, planował wykonać nowy dach na kościele oraz wybudować oborę, stodołę i nową plebanię 33 .

Kuciński Franciszek; ur. 16 września 1750 r.; święcenia kapłańskie przyjął 27 czerwca 1777 r. z rąk sufragana lubelskiego Kantego Lenczowskiego ${ }^{34}$; prowizję na wikariat w Koprzywnicy (parafia p.w. Wszystkich Świetych) otrzymał 21 maja 1777 r. Rekolekcje odprawił 4 maja 1782 r. Aprobatę do słuchania spowiedzi otrzymał 19 maja $1782 \mathrm{r}^{35}$.

${ }^{28}$ Protokót wizyty, s. 197-198.

${ }^{29}$ Tamże, s. 166.

${ }^{30}$ Tamże, s. 221.

${ }^{31}$ Wacław Hieronim Sierakowski (1699-1780), biskup przemyski, arcybiskup lwowski, por. P. Nitecki, Biskupi, kol. 401-402.

${ }^{32}$ Encyklopedia Wiedzy o Jezuitach na ziemiach Polski i Litwy 1564-1995, red. L. Grzebień, Kraków 1996, s. 330; Protokót wizyty, s. 179.

${ }^{33}$ Protokót wizyty, s. 179-180.

${ }^{34}$ Leńczowski Jan (?-1807), sufragan krakowski, biskup lubelski, por. P. Nitecki, Biskupi, kol. 243.

${ }^{35}$ Protokót wizyty, s. 130. 
W świetle wizytacji jawi się on jako kapłan gorliwy i pobożny, troszczący się o życie sakramentalne parafian. Na uwagą zasługuje fakt dobrego nauczania wiernych podstaw nauki katolickiej ${ }^{36}$.

Kuczęto Szymon; ur. 28 października 1729 r.; święcenia kapłańskie przyjął 9 kwietnia 1757 r. z rąk sufragana krakowskiego Franciszka Potkańskiego ${ }^{37}$. Instytuowany na probostwo kleczanowskie w Kielcach w 1770 r. Aprobatę do słuchania spowiedzi otrzymał 14 maja 1782 r. od oficjała sandomierskiego. Odprawił rekolekcje u OO. Reformatów w Sandomierzu ${ }^{38}$.

Był kapłanem pracowitym: zbudował nową dzwonnicę, otynkował kościół, w zakrystii została zrobiona nowa podłoga, zatroszczył się o nowy dach na plebani i rozbudowę zabudowań gospodarczych. W uwagach powizytacyjnych znajdujemy ponadto zalecenie wyzłocenia kielichów oraz zdjęcia ze ścian kościoła podartych obrazów i ich spalenie. Także ołtarze miały otrzymać nowe portatyle. ${ }^{39}$

Kwęcki Aleksy OP; ur. 25 kwietnia 1747 r.; profesje zakonną przyjął 14 lipca 1771 r.; od 28 marca 1781 r. brat zakonny przy klasztorze p.w. św. Marii Magdaleny w Sandomierzu ${ }^{40}$.

Lisowski Augustyn OP; ur. 5 marca 1733 r.; wstapił do zakonu w 1750 r.; święcenia kapłańskie przyjął 18 lipca 1756 r. z rąk sufragana krakowskiego Franciszka Potkańskiego ${ }^{41}$. Przeor klasztoru przy kościele p.w. św. Jakuba w Sandomierzu od 1 sierpnia $1779 \mathrm{r}^{42}$.

Malanowicz Wawrzyniec; ur. 11 sierpnia 1746 r., zm. w 1830 r. Święcenia kapłańskie przyjął 3 maja 1770 r. z rąk sufragana lubelskiego Kantego Lenczowskiego $^{43}$. Prowizję na wikariat w Malicach otrzymał 2 kwietnia $1781 \mathrm{r}$. w Kielcach. Aprobata do słuchania spowiedzi została wystawiona 2 lutego $1782 \mathrm{r}$. w Kielcach. Odprawił rekolekcje u oo. Dominikanów w Klimontowie 19 listopada $1781 \mathrm{r}^{44}$

Był kapłanem dbającym o chwałę Bożą, gorliwym, pobożnym i miłosiernym. W 1793 r. wyrestaurował kościół, uzyskał odpusty dla parafii w 1796 r. oraz zało-

\footnotetext{
${ }^{36}$ Tamże, s. $130-132$.

${ }^{37}$ Potkański Franciszek (1710-1789), sufragan krakowski, por. P. Nitecki, Biskupi, kol. 357-358.

${ }^{38}$ Protokót wizyty, s. 232-233.

${ }^{39}$ Tamże, s. 233.

${ }^{40}$ Tamże, s. 220-221.

${ }^{41}$ Potkański Franciszek (1710-1789), sufragan krakowski, por. P. Nitecki, Biskupi, kol. 357-358.

${ }^{42}$ Protokót, s. 227.

43 Jan Leńczowski (+1807), sufragan krakowski, biskup lubelski, por. P. Nitecki, Biskupi,

${ }^{44}$ Protokót wizyty, s. 239-240.
} kol. 243. 
żył nowy cmentarz w $1798 \mathrm{r} .{ }^{45} \mathrm{~W} 1804 \mathrm{r}$. został kanonikiem honorowym opatowskim. Zmarł w 1830 r. jako emeryt ${ }^{46}$.

Mikusiński Maciej; ur. 23 stycznia 1729 r.; święcenia kapłańskie przyjął 30 marca 1744 r. z rąk sufragana krakowskiego Franciszka Potkańskiego ${ }^{47}$. Prowizję na wikariat w Osieku przyjął 12 grudnia 1753 r. w Krakowie. Aprobatę do słuchania spowiedzi otrzymał w Sandomierzu na rok czasu od 14 lutego $1782 \mathrm{r}^{48}$.

Molęcki Rajmund OP; ex prowincjał; ur. 13 czerwca 1723 r.; profesję zakonną przyjął 17 października 1740 r.; wyświęcony na kapłana w lipcu 1747 r. W 1782 pracował w klasztorze p.w. św. Marii Magdaleny w Sandomierzu. Przyczynił się do odbudowy budynków klasztornych ${ }^{49}$.

Moszyński Ignacy; ur. 30 czerwca 1722 r.; święcenia kapłańskie przyjął we Włoszech w Ankonie w 1749 r. z rak lokalnego biskupa. Instytuowany na proboszcza w Łoniowie 25 maja $1781 \mathrm{r}$. w Krakowie; wprowadzony 7 czerwca $1781 \mathrm{r}$. Aprobatę do słuchania spowiedzi otrzymał 6 września 1781 r. na trzy lata ${ }^{50}$.

Kapłan ten był wskazywany przez wizytatora jako wzór skromności w życiu i służbie ludziom. W trosce o dobrą posługę sakramentalną wobec parafian, nabożeństwa były odprawiane w dogodnym dla nich czasie. Wielką pieczołowitością otaczał kościół i sprzęty parafialne. Potrafił, dzięki dużej wiedzy, głosić Słowo Boże w sposób jasny i przejrzysty ${ }^{51}$. Z pewnością nieocenioną pomocą w nauczaniu służyła biblioteka parafialna, która w tym czasie 100 woluminów ${ }^{52}$.

Mroczkowski Stefan OP; ur. w 1708 r.; w 1728 r. wstąpił do zakonu; święcenia kapłańskie przyją w 1734 r. Promotor różańca przy kościele p.w. św. Jakuba w Sandomierzu od $1782 \mathrm{r}^{53}$.

Olechowski Józef; ur. 28 kwietnia 1735 r. w Lubartowie z rodziny mieszczańskiejPawała Oleszko i Marianny Kwiatkowskiej; zm. 18 stycznia 1806 r. w Krakowie; herbu Ratuld, święcenia kapłańskie przyjął 22 marca 1760 r.; kustosz ol-

${ }^{45}$ Protokót wizyty, s. 239; Inwentarz parafii Malice z 1833 r. wymienia talar z 1764 r. z popiersiem Fryderyka Augusta, elektora saskiego, który był ofiarowany przez ks. W. Malanowicza (J. Wiśniewski, Dekanat, s. 92, 94).

${ }^{46}$ Bastrzykowski, A., Kolegiata św. Marcina w Opatowie i jej kapituła, cz. II, Katalog prałatów i kanoników kolegiaty opatowskiej od 1212 roku aż do dni naszych, Ostrowiec Świętokrzyski 1948, s. 51.

${ }^{47}$ Potkański Franciszek (1710-1789), sufragan krakowski, por. P. Nitecki, Biskupi, kol. 357-358.

${ }^{48}$ Protokól wizyty, s. 152-153.

${ }^{49}$ Tamże, s. 219; J. Zub, Z dziejów dominikańskiego klasztoru i kościoła św. Marii Magdaleny, ZS, 3 (1995) s. 24

${ }^{50}$ Tamże, s. 144-145.

${ }^{51}$ Tamże, s. 145 - 146.

${ }^{52}$ Tamże, s. 141.

${ }^{53}$ Tamże, s. 227-228. 
kuski, kanonik kielecki, krakowski, sandomierski, proboszcz w Sławkowie, Stopnicy; biskup sufragan krakowski od 1786 r. Instytuowany na probostwo w Obrazowie w Kielcach w 1767 r. Złożył legat 1000 zł. na szpital w Obrazowie ${ }^{54}$.

W opinii wizytatora był to wzór do naśladowania dla kapłanów w rządzeniu powierzonym sobie kościołem ${ }^{55}$.

Paprocki Michal OP; ur. 9 czerwca 1736 r.; profesję zakonną przyjął 7 maja 1753 r.; wyświęcony na kapłana 23 czerwca 1759 r. Pracował przy kościele p.w. św. Marii Magdaleny w Sandomierzu od 1 marca 1782 r. jako lektor ${ }^{56}$.

Raczyński Maciej; ur. 13 stycznia 1757 r.; święcenia kapłańskie przyjął 14 kwietnia 1781 r. w Krakowie z rąk sufragana krakowskiego Franciszka Potkańskiego $^{57}$. Wikariusz w Łoniowie od 1781 r. Aprobatę do słuchania spowiedzi otrzymał 6 czerwca $1781 \mathrm{r}^{58}$

Skarszewski Wojciech; ur. 1742 r. w rodzinie Marcina i Marii Szymborskiej; zm. 12 czerwiec 1827 r.; herbu Leszczyc, święcenia kapłańskie przyjął w 1776 r.; kanonik kamieniecki, wolborski, włocławski; proboszcz w Niesułkowie i Raciążku, Gdańsku; oficjał gdański; biskup chełmski od 1790 r., chełmsko - lubelski od 1805, arcybiskup warszawski od $1823 \mathrm{r}$. Instytuowany na probostwo w Chobrzanach 27 lipca 1775 r. Prowadził procesy z dziedzicami Chobrzan o utrzymanie kościoła; zakupił za 4000 zł. we wsi Goryczany ruiny starego zamku i kamień z niego wykorzystał do budowy kościoła ${ }^{59}$.

Sowicki Mateusz; ur. 11 listopada 1731 r.; święcenia kapłańskie przyjął 24 lipca 1763 r. w Lublinie z rąk biskupa Rajmunda Jeziorskiego ${ }^{60}$. Instytuowany na proboszcza w Niekrasowie 7 października 1768 r.; wprowadzony 6 listopada 1768 r. Aprobatę do słuchania spowiedzi otrzymał na jeden rok po okazaniu zaświadczenia o odprawionych rekolekcjach podpisaną przez Sebastiana Pisarskiego oficjała w Sandomierzu 25 października 1781 r. ${ }^{61}$

Początki pracy ks. Sowickiego w Niekrasowie były trudne. Kościół który objął, był bardzo ubogo wyposażony. Jednak dzięki pracy i wysiłkowi wspólnoty parafialnej, szybko uzupełnił świątynię w potrzebne aparaty liturgiczne. Wybudował ogrodzenie, zabudowania gospodarcze, ofiarował duży inwentarz. Rozpoczął

${ }^{54}$ B. Kumor, Olechowski Józef, SPTK t. 3, s. 243-245; W. M. Bartel, Józef Olechowski, PSB, t. 23 (1978), s. 738-739; M. Pęckowski, Józef Olechowski, archidiakon i sufragan krakowski 17351806, Kraków 1926; J. Wiśniewski, Katalog prałatów, s. 218-219; Protokół wizyty, s. 248.

${ }^{55}$ Tamże, s. $248-249$.

${ }^{56}$ Protokól wizyty, s. 220.

${ }^{57}$ Potkański Franciszek (1710-1789), sufragan krakowski, por. P. Nitecki, Biskupi, kol. 357-358.

${ }^{58}$ Protokót wizyty, s. 145.

${ }^{59}$ P. Nitecki, Biskupi, kol. 404; Protokót wizyty, s. 172; H. E. Wyczawski, Skarszewski Wojciech, SPTK t. 4, s. 92-94; J. Wiśniewski, Dekanat, s. 12-13.

${ }^{60}$ Rajmund Jezierski (1698-1782), biskup bakowski, por. P. Nitecki, Biskupi, kol. 183.

${ }^{61}$ Protokót wizyty, s. 159. 
budowę plebani. Na podstawie uwag powizytacyjnych, przed ks. Sowickim czekały jeszcze następujące prace: zrobienie dobrych zamków do tabernakulum, szafki na Oleje Święte, naprawienie podłogi w kościele, wykonanie sygnaturki oraz dokończenie plebani ${ }^{62}$.

Szajewski Jan; ur. 6 stycznia 1732 r.; święcenia kapłańskie przyjął 20 maja 1758 r. z rąk sufragana krakowskiego Franciszka Potkańskiego ${ }^{63}$. Proboszcz w Koprzywnicy (parafia p.w. Wszystkich Świętych) od 23 maja 1781 r.; parafie obją 9 lipca $1781 \mathrm{r}$. Rekolekcje odprawił 21 marca $1782 \mathrm{r}$. Aprobatę do słuchania spowiedzi odebrał 23 marca $1782 \mathrm{r}^{64}$.

Wizytator wskazał w protokole uchybienie, które rzutowały na negatywny wizerunek tego kapłana. Należały do nich: bark troski o kościół (dziurawy dach na świątyni i dzwonnicy, zniszczone ramy okien w kościele, porysowane i popękane sklepienie w zakrystii, przegniłe i próchniejące fundamenty plebani). Troski wymagały także naczynia liturgiczne (nie wyzłocone kielichy, popsute puszki na Najświętszy Sakrament do chorych). Ponadto kościół należało wyposażyć w nowe organy oraz szafy w zakrystii. Wizytator zalecił nadto budowę szkółki parafialnej oraz zatrudnienie nowego dzwonnika ${ }^{65}$. Na tym kapłanie ciążyło również oskarżenie, że za sprzedane srebra kościelne wziął dla siebie pieniądze, z którego to powodu wszczęto przeciwko niemu proces w Oficjalacie Sandomierskim. Zwrot długu miał nastapić z własnych dochodów kapłana. Miały one być wykorzystane na potrzebne remonty w kościele i na probostwie. Dziekan, który został zobowiązany do szczególnej troski o tego księdza, miał nadzorować prace służąc $\operatorname{rada}^{66}$.

Śliwiński Benedykt OP, ur. w 1725 r.; wstapił do zakonu w 1741 r.; święcenia kapłańskie przyjął w 1748 r., prezentat klasztoru przy kościele p.w. św. Jakuba w Sandomierzu od $1779 \mathrm{r}^{67}$

Świerczowski Idzi OP; ur. w 1725 r.; wstapił do zakonu w 1742 r.; święcenia kapłańskie przyjął w 1750 r. Pracował w klasztorze przy kościele p.w. św. Jakuba w Sandomierzu od $1781 \mathrm{r}$. Aprobatę do słuchania spowiedzi otrzymał od oficjała sandomierskiego ${ }^{68}$.

\footnotetext{
${ }^{62}$ Tamże, s. 159-160.

${ }^{63}$ Potkański Franciszek (1710-1789), sufragan krakowski, por. P. Nitecki, Biskupi, kol. 357-358.

${ }^{64}$ J. Wiśniewski, Katalog prałatów, s. 287; Protokół wizyty, s. 130.

${ }^{65}$ Protokót wizyty, s. 131-132.

${ }^{66}$ Tamże, s. 130.

${ }^{67}$ Tamże, s. 227.

${ }^{68}$ Tamże, s. 227-228.
} 
Treszczyński Dionizy; ur. 9 października 1750 r.; święcenia kapłańskie przyjął 7 grudnia 1777 r. z rąk sufragana krakowskiego Franciszka Potkańskiego ${ }^{69}$. Komendarz w Samborcu od 1781 r. $^{70}$

W świetle oceny wizytatora, był to kapłan pobożny i gorliwy, dbał o dobre sprawowanie sakramentów. Jednakże pewne uwagi wskazują, że należało większą troską otoczyć świątynię (palenie wiecznej lampki przed Tabernakulum, naprawa zamku i wzmocnienie szafki na Oleje Święte, poprawa zamknięcia chrzcielnicy, wybiałkowanie kościoła, zdjęcie podartych obrazów ze ścian, zwrócenie uwagi na sprzęty kościelne i bieliznę ołtarzowa, naprawa okien i dachu, odrestaurowanie ołtarza Pana Jezusa i sprowadzenie do niego lepszego obrazu). Ponadto ks. Dionizy miał odprawić zaległe rekolekcje ${ }^{71}$.

Tylkowski Józef; ur. 24 stycznia 1758 r.; święcenia kapłańskie przyjął 14 kwietnia 1781 r. z rąk sufragana krakowskiego Franciszka Potkańskiego. Aplikate na wikariat w Obrazowie otrzymał 26 maja 1781 r., zaś aprobatę do słuchania spowiedzi 12 marca 1782 r. po odprawionych rekolekcjach ${ }^{72}$.

Wiażewicz [Wązewicz] Waclaw; zm. w Warszawie w 1788 r., audytor generalny archidiecezji, kanonik katedry gnieźnieńskiej; proboszcz w Malicach od 1772 do 1784 r.; wprowadzony w 1772 r. ${ }^{73}$

Był on kapłanem troszczącym się o chwałę Bożą jednak wskutek przebywania poza parafią była ona zaniedbana. Plebania, dom organisty i komornika, szpital i zabudowania gospodarcze były stare i spróchniałe. Kościół miał dziurawy dach który groził zawaleniem. Wizytator zalecił więc utrzymywanie przy kościele drugiego księdza, by sprawował sakramenty i troszczył się o kościół $7^{74}$.

Życiński Ludwik OP; ur. 12 marca 1741 r.; profesję zakonną przyjął 10 października 1763 r.; święcenia kapłańskie otrzymał 6 grudnia 1765 r. Pracował od 10 kwietnia 1782 r. przy klasztorze p.w. św. Marii Magdaleny w Sandomierzu jako zakrystianin ${ }^{75}$.

\footnotetext{
${ }^{69}$ Potkański Franciszek (1710-1789), sufragan krakowski, por. Nitecki, Biskupi, kol. 357-358.

${ }^{70}$ Protokól wizyty, s. 184.

${ }^{71}$ Tamże, s. $184-185$.

${ }^{72}$ Tamże, s. 248.

${ }^{73}$ Wiśniewski, Dekanat, s. 94; Protokół wizyty, s. 238-239.

${ }^{74}$ Protokót wizyty, s. 239-240.

${ }^{75}$ Tamże, s. 221.
} 


\section{DER KLERUS DES DEKANATS KOPRZYWNICA IM LICHTE DER VISITATION VON 1782}

\section{Zusammenfassung}

Die Untersuchungen über den Pfarrklerus der polnischen Kirche in altpolnischer Zeit verfügen über eine lange und reiche Tradition. Sie präsentieren die Geistlichkeit sowohl unter geistigen (Vorbereitung zum Priestertum, intellektuelle und spirituelle Formation) als auch materiellen Gesichtspunkten (Gehalt, Verwaltung der Pfarrei). Die vorliegende Arbeit soll zum Kennenlernen dieser sozialen Gruppe auf dem Gebiet der als Dekanat bezeichneten Verwaltungseinheit der Diözesankirche beitragen. Das Dekanat von Koprzywnica gehörte im Berichtszeitraum zum Archidiakonat Sandomierz in der Diözese Krakau. Seine Gründung wird auf die Wende des 16./17. Jahrhunderts datiert. Im Jahre 1782 umfasste es 13 Pfarreien, und zwar: Chobrzany, Kleczanów, Koprzywnica, Łoniów, Malice, Niekrasów, Obrazów, Osiek, Samborzec, Sandomierz (Stiftskirche zur Geburt Unserer Lieben Frau, Kirche zur Bekehrung des hl. Apostels Paulus), Skotniki und Sulisławice. In den Grenzen des Dekanats befanden sich auch Mönchsklöster: das des Heilig-Geist-Ordens an der Heilig-Geist-Kirche sowie das der Dominikaner in Sandomierz: an der Kirche zum hl. Jakubus und zur hl. Maria Magdalena. Erwähnt werden müssen auch die Stiftskirche von Sandomierz sowie das Kloster der Reformatenpatres (Franziskaner) in Sandomierz, die aber in der Quelle nicht erfasst sind. Als Grundlage der durchgeführten Untersuchungen dienen die Akten der 1782 von P. Stanisław Ptaszyński durchgeführten Visitation, die sich in den Bibliotheksbeständen des Höheren Priesterseminars in Sandomierz befinden. Aus dem Text dieser Visitation geht hervor, dass im Dekanat Koprzywnica 22 Diözesangeistliche und 13 Ordensgeistliche tätig waren. Was die Art der ausgeübten Funktionen betrifft, so gab es im Dekanat 10 Pfarrer, 3 Klostervorsteher, einen Comendarius, 17 Vikare, einen Präbendarius, einen Kaplan, einen Rosenkranzförder und einen Ordensbruder. In der hier präsentierten Auflistung war ich bemüht, die Personalien der Geistlichen sowie jeweils eine auf der Grundlage der im Visitationstext enthaltenen Bemerkungen des Visitators angefertigte kurze Charakteristik zu liefern. 